\title{
COMMUNICATION RECEIVED FROM THE SOCIETY FOR THE DESTRUCTION OF VERMIN.
}

\author{
95, Wiamore STrReT, \\ LoNDoN, W. \\ July 7 th 1908. \\ TO THE EDITOR \\ THE JOURNAL OF HYGIENE, \\ FETTER LANE, E.C.
}

Sir,

\section{The War on Rats.}

In order to obtain accurate information regarding the nature and extent of the damage done by rats within the United Kingdom my Committee have prepared a schedule of questions which they desire to place into the hands of all those who are in a position, from their own experience, to give valuable information concerning temporary or permanent rat plagues in their districts, the damage inflicted by rats, the steps taken by them-individually or in co-operation with othersfor preventing such damage, the means chosen for that purpose, and the results obtained.

As the only means of gathering important knowledge of that kind is by favour of the Press-short of undertaking the appalling task of sending the questions to every one likely to suffer, or to have suffered, loss through rats, that is, to every householder in the country-my Committee venture to hope that you will permit an appeal to your readers to support the Society by asking for a copy of the schedule and returning it with such information as they may be able to impart.

I enclose a copy of the schedule for your information, and

$$
\begin{aligned}
& \text { am, Sir, } \\
& \text { your obedient servant, } \\
& \text { A. E. MOORE, } \\
& \text { Secretary. }
\end{aligned}
$$


(Schedule)

TELeGRAM8: "NIMREV, LONDON."

TELEPHONE No. 43 PADdinaton.

\section{THE INCORPORATED SOCIETY FOR THE DESTRUCTION OF VERMIN.}

President: Sir JAMms Criohton Browne, J.P., M.D., LL.D., F.R.S.

Vice-Presidents :

His Grace the DUke of Brdford, K.G. Thr RT. Hon. Lord AvebURt, P.C., D.C.L., F.R.S. Sir Patrick Manson, K.C.M.G., M.D., F.R.S. The Earl of DacketTh, D.L., J.P.

Sir Francis X. MacCabe, M.R.C.S., F.R.C.P. Surgeon Gev. A. F. Bradghaw, C.B., K.H.P., M.R.C.P. Sir Harry H. Johngton, G.C.M.G., K.C.B., D.Sc. Sir Gilbert Parker, D.C.L., M.P.

ProF. W. J. R. Simpgon, M.D., F.R.C.P.

HeNRY S. WeLcCOME.

Emir Zuschua (President L'Association Internationale pour la Destruction Rationnelle des Rats).

Hon. Treasurer: Sir Charles B. Maclaren, Bart., K.C., M.P. Secretary: A. E. MOORk.

95, Wigmore Street, LoNDON, W.

Daté

County of

Town (Village) of

Number of Inhabitants.

1. Name

(Profession, Trade, etc.)...

2. Description of place under report (state whether estate, farm, warehouse, factory, shop, etc.)

2A. Approximate area in square jards

2B. Number of persons living in the place

2c. Number of persons employed in the place

Total

2D. Describe the physical conditions of the district where your place is situated. Is there any factor farouring the existence of the rat plague?

3. How long has a rat plague existed, or how long have you been troubled with rats? 
4. What are the particular kinds of loss inflicted by the rats?
A. Destruction of Food
B. , , Material
C. " , Animal Life

4A. Can you approximately state in $f \mathrm{~s}$. d. the loss cansed in any one year?

$\begin{array}{ll}\text { in } 190 & \text { about } £ \\ \text { in } 190 & \text { about } £ \\ \text { in } 190 & \text { about } £\end{array}$

5. What means have you employed for destroying the rats (rat catchers, traps, bacteriological preparations, what kind) ?

5A. What was the cost per year?

About $\&$

5B. Were the rats exterminated?

5c. How long did your place remain free from rats after using such measures ?

6. In using a poison or a bacteriological preparation, have you suffered any loss through domestic animals dying from eating poison or virus, or eating rats killed with poison or virus? Please state full particulars.

7. Have you made any systematic efforts to deal with the rat trouble, either alone or in co-operation with others?

7A. If so, what were the means employed?

7B. What was the form of co-operation (state whether co-operation between neighbours, the residents of a parish, or several parishes, or of a rat and sparrow club)?

8. Can you state the approximate result of such systematio efforts?

Number of rats killed in 190

$\begin{array}{lll}\text {, } & \text { " } & 190 \\ \text {, } & \text {, } & 190 \\ \text {, } & \text {, } & 190 \\ \text {, } & \text {, } & 190\end{array}$

Remarks :

9. Can you mention any particular incidents illustrating the power of rats for doing injury? 
(Form A)

THE INCORPORATED SOCIETY FOR THE DESTRUCTION OF VERMIN, LONDON.

General Observations.

1. In your experience, what is the best means on the market for destroying rats?

(State what advantage it possesses in your opinion over other means).

2. Are you in favour of a proposal to multiply the number of the existing Rat and Sparrow Clubs, organising and co-ordinating them with similar agencies working for the extermination of rats?

3. If so, are you in favour of an annual grant being made by the State for that purpose, of say $£ 10,000$ ?

\section{(Form B)}

THE INCORPORATED SOCIETY FOR THE DESTRUCTION OF VERMIN,

\section{LONDON.}

Statistics.

1. Is it in your opinion reasonable to assume (for the purpose of estimating the loss caused by rats, by the destruction of private and public wealth) that there is at least one rat to each acre of the total acreage of the United Kingdom?

2. Is it in your opinion reasonable to assume that the number of rats present on farms, in hamlets and villages is at least equal to the number of inhabitants?

3. Considering the greater facilities provided for rats in the towns, as regards food and hiding places, is it reasonable to assume that there are also in towns as many rats as there are human beings?

4. Is it in your opinion reasonable to estimate the economic loss caused by rats (through eating and spoiling food and destroying material) at one farthing per rat per day? 